\title{
(2) OPEN ACCESS \\ Varicella caused by airborne transmission of a localised herpes zoster infection in a family
}

\author{
Yumi Hatsushika, Isao Nii, Tomohiro Taniguchi
}

General Internal Medicine \& Infectious Diseases, Hiroshima Prefectural Hospital, Hiroshima, Japan

\section{Correspondence to Dr Yumi Hatsushika: yumi.hats@gmail.com}

Accepted 4 July 2021

Check for updates

(c) BMJ Publishing Group Limited 2021. Re-use permitted under CC BY-NC. No commercial re-use. See rights and permissions. Published by BMJ.

To cite: Hatsushika Y, Nii I, Taniguchi T. BMJ Case Rep 2021;14:e243217 doi:10.1136/bcr-2021 243217

\section{SUMMARY}

Localised herpes zoster infections spread by direct contact with active skin lesion, but airborne transmission is rare. We report a case of varicella from airborne transmission of a localised herpes zoster infection in a family. The patient was a 15-year-old boy who had never been vaccinated against the varicella-zoster virus (VZV). He likely developed varicella from his father, whom the patient lived with. The patient's father developed a localised herpes zoster infection 2 weeks prior. The patient's varicella was hypothesised to be due to VZV spread via airborne transmission from the father's localised infection. To decrease the number of varicella cases, routine vaccination of children against VZV is essential, and immunisation against VZV in middle-aged and elderly patients is also necessary.

\section{BACKGROUND}

Varicella, also known as chickenpox, can be easily spread via airborne transmission. ${ }^{1}$ Herpes zoster, also known as shingles, is caused by reactivation of the varicella-zoster virus (VZV) that reached the sensory ganglia during varicella. Localised herpes zoster infections spread by direct contact with an active lesion, which is usually a rash, and it will not spread through the air unless it becomes a disseminated infection. ${ }^{2}$

Varicella is a vaccine-preventable disease. However, in Japan, there are many patients who have never been vaccinated against varicella because routine VZV vaccinations only started in 2014, which was later than other developed countries. For people over 50 years old, a zoster vaccine is available, but it is not generally well accepted.

In this case report, the patient had never been vaccinated against VZV because the vaccination programme was voluntary when he was a child. His father, whom the patient was living with, developed a localised herpes zoster infection first. The patient developed varicella 2 weeks after his father's herpes zoster infection. This case suggests that for unvaccinated patients living in a house where the distance between people is very close, a localised herpes zoster infection can spread through the air.

\section{CASE PRESENTATION}

The patient is a 15-year-old adolescent boy without a previous medical history. $\mathrm{He}$ lives with his parents and his 8-year-old brother. His mother developed varicella in her childhood, and the patient's brother had been vaccinated against VZV. However, the patient was never vaccinated against VZV, as confirmed in his vaccination record book, because the vaccine programme was voluntary when he was a child. A fever and sore throat started and continued for 4 days before the patient came to our hospital. His fever was over $38^{\circ} \mathrm{C}$, and he experienced chills. Two days later, he visited a clinic with his father because his stomachache had not improved for the past 2 weeks. His father was diagnosed with a localised herpes zoster in his left abdomen. The patient also had rashes and blisters all over his body. Varicella was suspected, and acetaminophen and valaciclovir hydrochloride were prescribed. However, he developed a headache and nausea and was subsequently referred to our hospital for a more detailed examination. His vital signs were as follows: blood pressure of $102 / 67 \mathrm{~mm}$ $\mathrm{Hg}$, heart rate of $71 / \mathrm{min}$, respiratory rate of $12 /$ min, body temperature of $36.7^{\circ} \mathrm{C}, \mathrm{SpO}_{2}$ of $99 \%$ (on ambient air). Although the patient appeared to be sick, his Glasgow Coma Scale was 15/15, and his cognition was clear. On physical examination, both pupils were $5 \mathrm{~mm}$ with a normal light reflex. No papilloedema was observed. There were no signs of a rash on his eye conjunctiva and in his mouth. His neck was easily movable and nuchal rigidity was negative. There were rashes and blisters around his forehead (figure 1), body (figure 2) and four limbs. Part of his rashes became crusty.

\section{TREATMENT}

Based on the patient's medical history and the state of his rash, his clinical diagnosis was varicella. Because his cognition was clear, herpes zoster-associated meningitis or encephalitis was not suspected. We continued treatment with valaciclovir hydrochloride, as initially prescribed.

\section{OUTCOME AND FOLLOW-UP}

The patient's IgG and IgM levels for VZV were positive, and the diagnosis of varicella was confirmed. After he continued taking valaciclovir hydrochloride for a few days, his fever resolved and the rash disappeared. He denied direct contact with his father's herpes zoster lesions. His mother and brother did not become sickened with varicella.

\section{DISCUSSION}

In this case, airborne transmission of VZV from a localised herpes zoster infection of the patient's father spread to the unvaccinated patient in the house. This caused the patient to become sickened with varicella.

In Japan since 1999, around one million patients sickened with varicella were estimated to visit a doctor each year. After routine vaccination against 


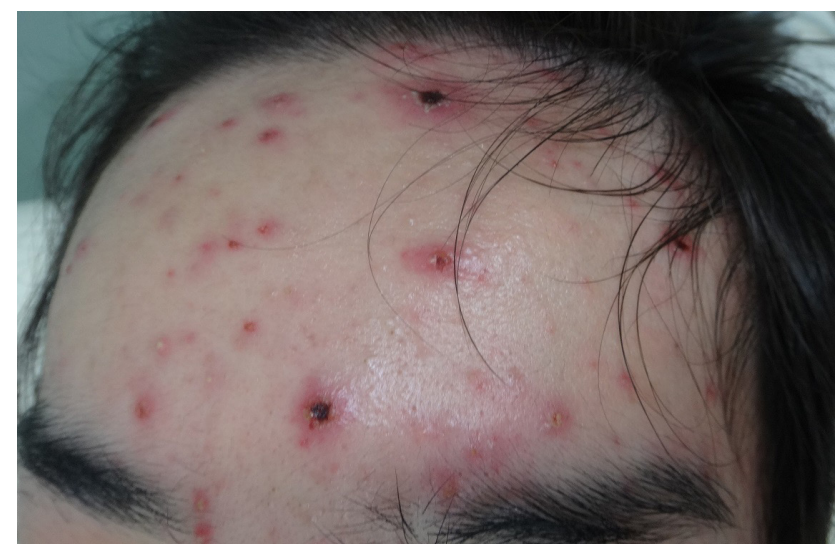

Figure 1 Image of blisters and rashes on patient's forehead and chest from suspected varicella.

VZV started in 2014, reported varicella cases decreased less than one-fourth. ${ }^{3}$ However, unvaccinated patients still exist, and the number of them with no previous exposure to VZV is unknown.

Varicella's incubation period is $14-16$ days on average. ${ }^{1}$ In this case, the patient's father had left-side abdominal pain from the herpes zoster 2 weeks before the patient was diagnosed with varicella. He did not touch his father's herpes zoster rash. This suggests that VZV is very likely to spread via airborne transmission at home. Almost all cases of herpes zoster are associated with a viremia, which would carry virus to the nose and throat. ${ }^{4}$ In one report, individuals with herpes zoster who had covered rashes on the trunk and those who had exposed rashes on the arms or hands were equally likely to spread VZV. ${ }^{5}$ Therefore, a localised herpes zoster infection anywhere on the body can be the cause of airborne transmission. ${ }^{67}$ This is an important issue for isolation precautions in hospitals. The Centers for Disease Control and Prevention guidelines, last updated in 2007, call for only standard precautions and covering of zoster lesions in patients with localised herpes zoster. However, some reports have appealed for stricter quarantine measures to be applied as they are for other diseases with airborne transmission. ${ }^{8-10}$

To decrease the number of patients affected with varicella, a national immunisation programme for unvaccinated children is essential. To identify unvaccinated people, an antibody screening test may be optional, for example, when these individuals enrol at a university or when they are employed. Furthermore, middleaged and elderly individuals are recommended to take the zoster

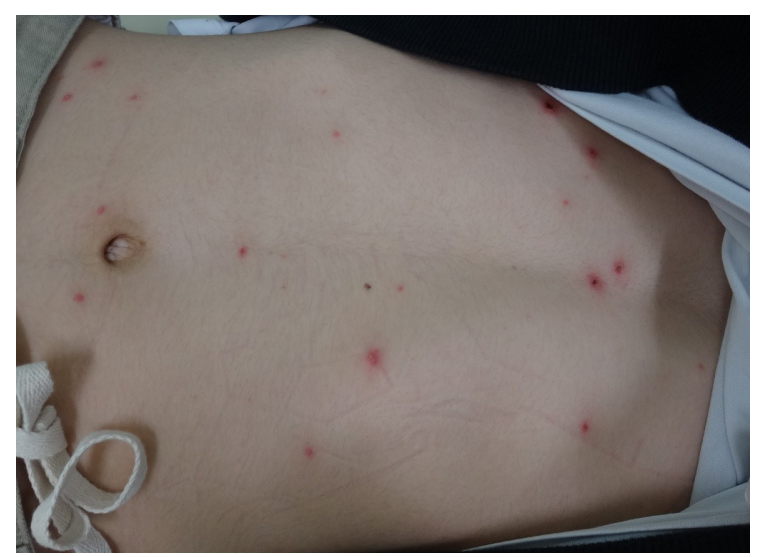

Figure 2 Image of blisters and rashes on patient's forehead and chest from suspected varicella. vaccine. Some countries have already introduced VZV vaccination programmes for the elderly. ${ }^{11}{ }^{12}$ In Japan, the VZV live vaccine called Zostavax is available to individuals over 50 years old, but the use of vaccine is limited. The morbidity rate for adult patients with herpes zoster is suspected to remain relatively high and will increase as the population continues to become older. Many people suffer from complications associated with herpes zoster including postherpetic neuralgia. To decrease herpes zoster infections and also to protect individuals who have not yet received the vaccine, routine zoster vaccinations for individuals 50 years and older are highly recommended, because a localised herpes zoster infection can easily be transmitted via the airborne route to unvaccinated members of a family living in the same home. However, adults who are immunosuppressed generally should not receive live zoster vaccine bacause of the risk of disseminated infection. Three deaths have occurred after Zostavax immunisation of immunocompromised elderly people. ${ }^{13}$ Instead, a new inactivated vaccine called Shingrix has become available since 2020 in Japan.

\section{Learning points}

Under very close distances, such as in one's home, people who are not vaccinated against varicella can be infected from a localised herpes zoster infection via the airborne route.

- To decrease varicella cases, routine administration of the varicella vaccine in children and the zoster vaccine in adults is highly recommended.

Contributors YH drafted the manuscript. IN and TT helped to draft the manuscript. All authors have read and approved the final manuscript.

Funding The authors have not declared a specific grant for this research from any funding agency in the public, commercial or not-for-profit sectors.

Competing interests None declared.

Patient consent for publication Parent/guardian consent obtained.

Provenance and peer review Not commissioned; externally peer reviewed.

Open access This is an open access article distributed in accordance with the Creative Commons Attribution Non Commercial (CC BY-NC 4.0) license, which permits others to distribute, remix, adapt, build upon this work non-commercially, and license their derivative works on different terms, provided the original work is properly cited and the use is non-commercial. See: http://creativecommons.org/ licenses/by-nc/4.0/.

\section{REFERENCES}

1 The centers for disease control and prevention. chickenpox (varicella). Available: https://www.cdc.gov/chickenpox/hcp/index.html [Accessed 19 Jun 2021].

2 The centers for disease control and prevention. shingles (herpes zoster). Available: https://www.cdc.gov/shingles/hcp/index.html [Accessed 19 Jun 2021].

3 National Institute of infectious diseases, Japan IASR, 2018. Available: https://www. niid.go.jp/niid/en/iasr-vol39-e/8268-462te.html [Accessed 19 Jun 2021].

4 Satyaprakash AK, Tremaine AM, Stelter AA, et al. Viremia in acute herpes zoster. J Infect Dis 2009;200:26-32.

5 Lachiewicz AM, Srinivas ML. Varicella-Zoster virus post-exposure management and prophylaxis: a review. Prev Med Rep 2019;16:101016.

6 Josephson A, Gombert ME. Airborne transmission of nosocomial varicella from localized zoster. J Infect Dis 1988;158:238-41.

7 Lopez AS, Burnett-Hartman A, Nambiar R, et al. Transmission of a newly characterized strain of varicella-zoster virus from a patient with herpes zoster in a long-term-care facility, West Virginia, 2004. J Infect Dis 2008;197:646-53.

8 Ahronowitz I, Fox LP. Herpes zoster in hospitalized adults: practice gaps, new evidence, and remaining questions. J Am Acad Dermatol 2018;78:223-30.

9 Red Book. American Academy of pediatrics Committee on infectious diseases: red book. 31 edn. IL: AAP Elk Grove Village, 2018.

10 Zuckerman RA, Limaye AP. Varicella zoster virus (VZV) and herpes simplex virus (HSV) in solid organ transplant patients. Am J Transplant 2013;13 Suppl 3:55-66.

11 Amirthalingam G, Andrews N, Keel P, et al. Evaluation of the effect of the herpes zoster vaccination programme 3 years after its introduction in England: a populationbased study. Lancet Public Health 2018;3:e82-90. 
12 Litt J, Booy R, Bourke D, et al. Early impact of the Australian National shingles vaccination program with the herpes zoster live attenuated vaccine. Hum Vaccin Immunother 2020;16:3081-9.
13 Dubey V, MacFadden D. Disseminated varicella zoster virus infection after vaccination with a live attenuated vaccine. CMAJ 2019:191:E1025-7.

Copyright 2021 BMJ Publishing Group. All rights reserved. For permission to reuse any of this content visit

https://www.bmj.com/company/products-services/rights-and-licensing/permissions/

BMJ Case Report Fellows may re-use this article for personal use and teaching without any further permission.

Become a Fellow of BMJ Case Reports today and you can:

- Submit as many cases as you like

Enjoy fast sympathetic peer review and rapid publication of accepted articles

- Access all the published articles

Re-use any of the published material for personal use and teaching without further permission

Customer Service

If you have any further queries about your subscription, please contact our customer services team on +44 (0) 2071111105 or via email at support@bmj.com.

Visit casereports.bmj.com for more articles like this and to become a Fellow 